\title{
An obstetrics and gynaecology graduate residency programme in Venezuela
}

\section{Summary}

We present our experience on the design and development of a gynaecology and obstetrics graduate residency programme, developed in the Department of Obstetrics and Gynecology at the Dr Adolfo Prince Lara Hospital, Puerto Cabello, Venezuela, in which medical specialists and residents participate synergistically. From January to September 1993, curricular activities were planned and students selected. The programme started in October 1993, with six residents for a three-year programme. Courses were given by medical specialists from the Department. In addition to a Programme Coordinator, there is also a Residents' Coordinator, appointed for a twomonth term of office; specific functions were assigned for residents occupying this position. All the programmed activities for three years were accomplished, including lectures and rotations, with an important record of surgical interventions. In our grade system, residents got an average of 18 over a maximum of 20 points. Residents also participated as speakers in workshops, special courses and national medicinal meetings, in which they presented a total of nine papers. Activities were evaluated bimonthly in meetings with students and each semester by the Graduate Committee. The first class graduated in September 1996. Results suggest that resident participation in graduate programmes is an important part of their education.

Keywords: residency programmes; education

\author{
Department of Obstetrics and \\ Gynecology, Hospital \\ 'Dr Adolfo Prince Lara', \\ Puerto Cabello, Estado Carabobo, \\ Venezuela \\ P Faneite
}

Correspondence to Pedro Faneite MD, Jet Cargo Intl M 510, Fundación CID, Box 020010, Miami, FL 33102, USA

Accepted 16 April 1997

\section{Pedro Faneite}

In our hospital we believe that patient assistance, teaching and research, should work together for the benefit of the patient and for better academic results. During the last decades of this century, we are changing many aspects of the teaching-learning process, especially in the field of obstetrics and gynaecology. Changing circumstances, such as in instructor/resident and doctor/patient ratios, financial resources, and others, have forced planners to look for new alternatives, so that professionalism and efficiency can be maintained at the same time as high academic standards. ${ }^{12}$

In Venezuela's most important hospitals in Caracas, and in the main state hospitals (Mérida, Zulia, Carabobo), we have observed some difficult situations requiring solution, such as the existence of too few positions for graduate students, scarce financial resources, together with a high cost of living. This requires each region to make an effort in order to educate their professionals, in particular medical doctors, according to the local needs and using all available resources.

At the Dr Adolfo Prince Lara Hospital, and at the request of the medical residents, we designed and established a graduate residency programme in obstetrics and gynaecology. An important fact was that the medical residents themselves, as well as medical specialists in obstetrics and gynaecology, training as teaching instructors, participated in the design and development of the programme. All programme activities were developed under the direction of the Department Council, as in other programmes of this type..$^{3-6}$ A three-year residency programme was designed, including subjects as clinical practice, physiology, pathology, patient examination, diagnosis and treatment of diseases related to gynaecology and obstetrics. We also wanted our medical doctors to be aware of the psychosocial aspects of their patients and the community. We obtained support from our state medical college and the Venezuelan Medical Federation, and are working to get academic recognition from our state university, Universidad de Carabobo, and financial support from the Ministry of Health.

\section{Methods}

A three-year graduate residency programme in obstetrics and gynaecology was designed and developed at Dr Adolfo Prince Lara Hospital in Puerto Cabello, Venezuela. The design and development of this programme included the following stages:

PHASE I JANUARY-AUGUST 1993

Integration of the Preparatory Committee by residents and medical specialists; review and analysis of programmes from other state hospitals and university hospitals; establishment of a financial fund; organisation, editing and publication of the programme; meetings with medical doctors from the obstetrics and gynaecology department; approval of the experimental programme by hospital authorities.

PHASE II SEPTEMBER-OCTOBER 1993

Application and selection of residents; design of teaching strategies (shared responsibility, designation of Residents' Coordinator); department Council meetings; designation of programme coordinator; establishment of secretarial services and files.

PROGRAMME INITIATION OCTOBER 1993

Residents' participation is the responsibility of the Residents' Coordinator, who is designated every two months and who is responsible to the Programme Coordinator and his peers for the efficiency of the programme. His activity is evaluated at bimonthly meetings where he has to report on the objectives 
Table 1 Curriculum for the Gynecology and Obstetrics Graduate Residency Programme at the Dr Adolfo Prince Lara Hospital, Puerto Cabello, Venezuela

\begin{tabular}{lll}
\hline First year & Second year & Third year \\
\hline Basic anatomy & Obstetric pathology & Gynaecological surgery \\
Obstetric physiology & Gynaecology & Internal medicine \\
Basic pathology & Anatomical pathology & Oncology \\
Surgical techniques & Perinatology & Mastology \\
Family planning & Infertility & \\
\hline
\end{tabular}

Table 2 Number of activities attended by residents in the Gynecology and Obstetrics Graduate Residency Programme at the Dr Adolfo Prince Lara Hospital, Puerto Cabello, Venezuela (average number of activities per resident)

\begin{tabular}{llll}
\hline Activity & First year & Second year & Third year \\
\hline Lectures & $42 h$ & $59 h$ & $41 h$ \\
Seminars & 26 & 19 & 36 \\
Case presentations & 10 & 22 & 9 \\
Review of published articles & 10 & 6 & 10 \\
Clinical history discussions & 19 & 15 & 6 \\
Rotations & 6 & 6 & 452 \\
Surgical record & 82 & 273 & $(353-573)^{\star}$ \\
Patients attended & $(53-177)^{\star}$ & $(133-319)^{\star}$ & 230 \\
Patients in labour & 58 & 154 & $(202-273)^{\star}$ \\
Cesarean sections & $(49-95)^{\star}$ & $(111-191)^{\star}$ & 4 \\
Research papers presented at national & 3 & 2 & 6 \\
$\quad$ meetings & 6 & 6 & 2 \\
Meetings with Program Coordinator & 2 & 2 & \\
Meetings with Department Council & & & \\
\hline
\end{tabular}

^ Range.

accomplished. He also is responsible for representing residents before higher authorities of the programme and the hospital, and for the administration of a financial fund created by voluntary donations of residents for common expenses. The Residents' Coordinator is also responsible for coordinating lectures and collection of evaluations of rotations and other activities.

\section{Results}

The gynaecology and obstetrics residency programme started in October 1993 with the curriculum of courses shown in table 1 . Activities performed by graduate residents from October 1993 to October 1996 are presented in table 2.

Our students obtained an average grade of 17.5/20 (17-18), 18.6/20 (18-19) and 18.35/20 (18-18.6) during the first, second and third year, respectively. At the end of this period, a final report was sent to the hospital authorities and Venezuelan Medical Federation.

teaching-learning process, residents were given direct participation in the coordination of programme activities

- residents' opinions were taken into account for the design of the programme

- a designated Residents' Coordinator, acting for a two-month period, was responsible to the Programme Director for programme activities. $\mathrm{He}$ also was responsible for the administration of a financial fund for common expenses

- the Residents' Coordinator presented a report of activities and support received from other residents, and also of expenses during his term of office

- all programmemed activities were accomplished, including teaching and research

- results suggest that residents' participation in graduate residency programmes in administrative activities such as coordinators, is a positive move, both for our professionals and for the development of academic programmes in our hospitals

\section{Discussion}

We are prompted to report our experience because this type of programme is being conducted on an experimental basis, in contrast with many programmes established in our university hospitals and other important hospitals, which get academic recognition from the universities with which they are associated. We would like to receive input from colleagues in other countries and hospitals in order to improve our programme.

The high level of residents' participation has meant that the students provide the motivation to keep this programme going. Our results show that our residents have obtained not only an academic education in basic medical disciplines, but also considerable experience in clinical assistance to gynaecological and obstetric patients. This can be seen by the surgical record, both in attending to patients in labour and to those subjected to Caesarean section.

Although our students have had the opportunity to review literature in other languages, especially in English, in order to prepare seminars and to present clinical cases, we are aware of the need for them to improve their knowledge of foreign languages, particularly English, since most of the literature we have access to is published in English. We also believe that a knowledge of statistics is necessary for the conduct, critical review and appraisal of clinical research. In this regard, we have obtained support from different services and the hospital for residents' research activities.

All obstetrics and gynaecology specialists in our department have had the opportunity to participate in teaching or coordinating activities, which 
1 Armbruster J. Accreditation of residency training in the US. Postgrad Med $\mathcal{F} 1996 ; 72: 391-4$.

2 Panayiotou B, Fotherby M. Junior hospital doctors' view on their training in the UK. Postgrad tors view on their training
Med $\mathcal{1} 1996 ; 72: 547-50$.

3 Eskew P, Watt G. Postgraduate medical education in obstetrics and gynecology. Obstet Gynecol 1981;58:642-5.

contributed to the programme's success. Our results exceeded our expectations, since we accomplished all the planned activities, both theoretical (ie, lectures and seminars) and practical (clinical rotations and surgical activity). Our residents also participated in research activities and attended national meetings presenting the results of their research. Their grades also show the quality of their achievements.

Finally, we conclude that resident participation in graduate residency programmes is a valid strategy in the process of graduate teaching in our region.

4 McGill F, Kleiner G, Vanderbilt C, Nieves J Postgradute internship in gynecology and obstetrics for physicians assistants: a 4 year obsterience. Obstet Gynecol 1990;76:1 135-9.

5 Droegemueller W. Symposium on the qualificaDroegemueller W. Symposium on the qualifica-
tions of a director of an obstetrics-gynecology tions of a director of an obstetrics-gynecology 156:876-84.
6 Martey J, Elkins T, Wilson J, Adadevoh S. Innovative community-based postgraduate training for obstetrics and gynecology in West Africa. Obstet Gynecol 1995;85:1042-6. 